\title{
EVOCAÇÃO DO PROFESSOR ALFREDO BETÂMIO DE ALMEIDA Homenagem dos 100 anos de nascimento (1920.02.17-1985.02.15)
}

\section{Homenagem APECV e InVisibilidades}

\author{
Elisabete Oliveira
}

Associação de Professores de Expressão e Comunicação Visual

\section{INTRODUÇÃO}

Nesta reflexão sobre a obra de Alfredo Betâmio de Almeida ( $A B A)$, pioneiro da Arte-Educação em Portugal, focamos:

\section{As dimensões da obra de Betâmio}

Desde os anos 70, em investigação prosseguida para Doutoramento FPCE.UL de 2005, sustentamos uma concepção da Estética como orientação da energia transformadora para a qualidade (qualia, carácter), na criação ou apreciação
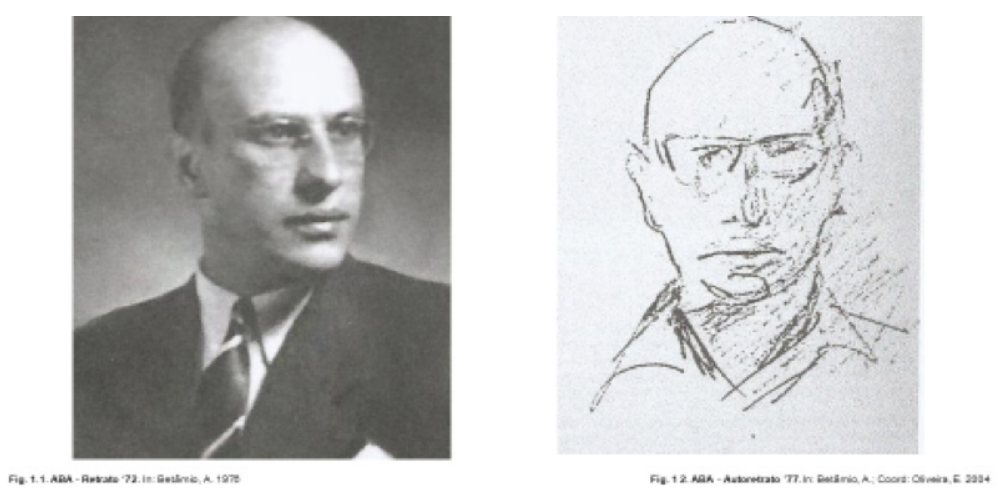
da forma: em três dimensões (d) - funções (f); e $A B A$, pela multiplicidade e pioneirismo da sua obra educacional, cultural e cidadã, será um seu referencial:

(1) d. material-f. tecnológica: Didáctica e Recursos escolares para Educação Estética Visual a garantir a todos, especialmente na Escola pública, entretecidos com InvestigaçãoAcção; / Metodologia ('57-'72); Programação e Operacionalização de Telescola; Curso propedêutico-TV e pró-Universidade Aberta; Apoio a Professores. / Luta pelo espaço-tempo e Recursos Educacionais: Criação de Compêndios, Livros e Artigos. / Pintura: expressionismo e experimentalismo matérico-técnico: sem divulgação, mas por necessidade de reflexão, descoberta-expressão e fazer a mão.

2) d. social - f. comunicativa: Investigação das raízes-envolvente histórica, da Educação Estética Visual, da Observação e da Semiótica, escrevendo/partilhando continuamente. / Serviço de responsabilização cívica, até como gestor (V-Reitor L. N. P. Nunes ('68-'74); Director DGES ('74-'75); Inspector-Geral MEIC, Lançamento do Eo Unificado ('75-); Gestor JICU ('76); Director ITE ('77-'85, morte). / Desenho e Pintura, ligados ao usado, do quotidiano, na interacção do viver pessoalprofissional - Hoje, o professor usa o processo mental criativo do artista como um processo pedagógico (Betâmio, 2007).

3) d. ontológica - f. organização-de-vida: Busca de sentido de Ser-Agir, do visível ao invisível, do possível ao imaginável; reflexão partilhada, criando Arte 
- o concreto, desmaterializado ou geometrizado; barcos em festa de cor -, até Janeiro de '85, véspera do fim.

Consideramos ABA em Educação Estética Visual (EEV), com Arquimedes da Silva Santos (Centenário em 2021) em Psicopedagogia das Expressões Artísticas, os vultos mais relevantes da Arte-Educação de Portugal, na 2 a metade do séc. XX.

\section{Dimensão Material - Função Tecnológica}

Nesta dimensão, englobamos as seguintes modalidades de acção de ABA:

\subsection{Didáctica e Recursos escolares para Educação Estética Visual (EEV)}

Busca garantir EEV a todos, especialmente na Escola pública, entretecida com Investigação-Acção.

É pioneiro em Metodologia; Programação e Operacionalização de Telescola; Curso propedêutico-TV e pró-Universidade Aberta e Formação de Professores.

Luta pelas condições de espaço-tempo para a aula e cria Recursos Educacionais como os Compêndios; escreve Livros e Artigos.

Em Pintura desenvolve expressionismo e experimentalismo matérico-técnico: sem divulgação, mas por necessidade de reflexão, descoberta-expressão e fazer a mão.

Por '75, os Exercícios formais generalizados no Ensino especialmente após o Programa bauhausiano de '70 por Equipa coordenada por $\mathrm{ABA}^{1}$-, deram progressivamente lugar ao Trabalho de Projecto.

ABA foi Pioneiro da Metodologia de Projecto sistemática, c. 1967 - após o caso pontual que recolhemos em Ficha do ExplorEAUL, de João Martins da Costa, c. 1955: Projecto Ciclo da Água - desenho por alunos com visita ao porto de Leixões, criação de expositores em madeira e exposição na escola.

ABA coordenou também a equipa que, com Danilo Sobral e Elisabete Oliveira, programou a Opção Vocacional Arte/Design para o 9o ano do Ensino Unificado (desde '77-'78) - integrando um professor de Trabalhos Oficinais em parte das aulas -, a qual, em nossa Investigação de Doutoramento ('05), verificámos ter abrangido 90 escolas durante 15 anos, em Portugal, com desenvolvimentos de curto até longo prazo -. Só nos anos '90. meia década após a sua morte, se generalizaria o Projecto de Trabalho, com crescente iniciativa/autonomia dos azulejo, para a parede de entrada da escada para a Salas 33 - Desenho, de Betâmio no Liceu Normal de Pedro Nunes, Lisboa -, c. 250×150cm, por 1967. ABA orientou uma turma do 4-o Ano (c. 14 anos) que fez maquetas em A4, a guache: eleito o painel do aluno Vespeira, concretizaramno e, antes de instalado, foi exposto na Sala dos Professores - na foto -, que ABA usava para as exposições escolares anuais de Desenho/ Educação Visual (e onde se realizavam as Conferências finais dos Estágios, abertas à comunidade do âmbito científico dos Estágios de todos os Grupos). Este painel, destruído, como tanto património cultural escolar desprezado, consta da Ficha 18 do Exploratório de Educação Artística da Universidade de Lisboa, ExplorEAULPiloto. (Investigação e Foto Elisabete. Oliveira). alunos.

1 Equipa: Prof. Lacerda Ferreira e Ex-Estagiários, Danilo Sobral, Elisabete Oliveira, Fernando e Sílvia Sá Dantas, Maria Eugénia Viola e Maria Luísa Abelha. No começo de 1970, juntou-se-Ihe Luis Gonçalves, que sucederia a ABA na Metodologia em 1974. 
Fig. 3. Reformas do Ensino do Desenho 18601960 - Investigação de Betâmio, A. (1967): Metodologias, tempos lectivos** Prosseguida até 2010: In: Oliveira, E. (2010).

** Em 1969 chegara-se a redutor 1 tempo semanal em Desenho: ABA conseguiu oficialização de 3.

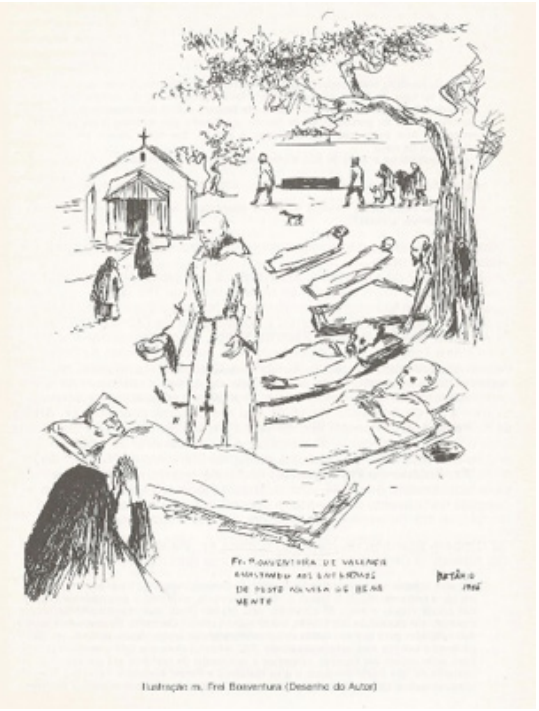

Fig. 4. Desenho de ABA, 1956:

Fr. Boaventura de Valença assistindo aos enfermos da peste na Vila de Benavente. In Betâmio, A. (1990). O Convento de Jenicó, CMB,
Sobre Educação Estética Visual e Arte: além do Compêndio de Desenho desde 1948 e Crítica na Imprensa, mais sistemática no Diário de Lisboa, ABA publica o primeiro dos seus Livros referenciais:

Ensaios para uma Didáctica do Desenho. Lisboa: Escolar Editora. 1967.

Educação Estética. Palestra № 31. Janeiro de 1968, seminal da mudança curricular bauhausiana de 1970 (com a sua Equipa atrás mencionada): o valor formativo da apreciação e da composição passa para os alunos.

A Educação Estético-Visual no Ensino Escolar. Lisboa: Livros Horizonte. 1976.

\section{REFORMAS DO ENSINO DO DESENHO - 1860.1960}

Investigação, Alfredo Betâmio de Almeida

$\mathrm{Nb}$ : Por E. Oliveira de 1960 até $2010 \ldots$

1970 - Programas Bauhausianos

1974 - Programas de transição pós-25 Abril '74

1975. - Programas do $E^{\circ}$. Unificado - Reforma

Veiga Simão, cl acentuação tecnológica desde 1990.

\section{EDUCAÇÃO ESTÉTICA VISUAL 1936-2010}

Investigação de Elisabete Oliveira

Excertos in: Oliveira, E. 2010.

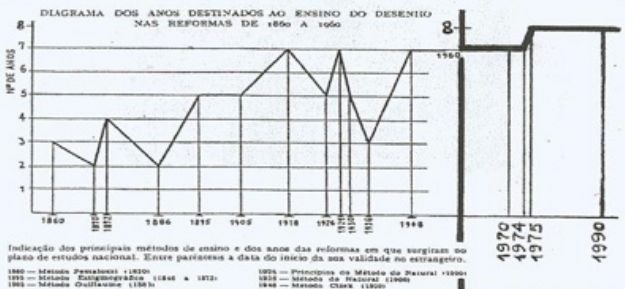

Daqui partirāo os 7 períodos de desenvolvimento que identificamos como relevantes na EEV.

P1: 1936 - 1947/8. Pró - Imaginação

P2: $1947 / 8$ - 1970. Educaçăo através da Arte

P3: 1970 - 1974. Formal

P4: 1974 - 1975. Cultural - Comunicativo

P5: 1975 - 1990. Integrado - Envolvimentalista

P6: 1990 -2001/04. Funcional - Tecnológico

P7: 2001/04 - (-). Interaccional - Eco-Tecnológico

Designámo-los pela acentuação de novas caracteristicas que vislumbrámos no enunciado dos seus objectivos/capacidades a desenvolver; e pelas competências a impulsionar pela operacionalizaçăo proposta para esses objectivos.

\subsection{Paralelamente, $A B A$ foi construtor de memória-património cultural}

. Sobre as raízes, em Benavente: investiga e publica pela CM Benavente, 1953; e prepara O Convento de Jenicó, - sobre os Frades neste local de Benavente hoje ruína onde se vai a S. Baco pedir a salvação das pragas agrícola; e sobre o Palácio e a Corte em Salvaterra de Magos -, saindo um Capítulo mas que só será publicado postumamente em 1990. 
Em 24.11.1947, ABA concebe o Desenho Livre, que consegue oficializar em 1948.

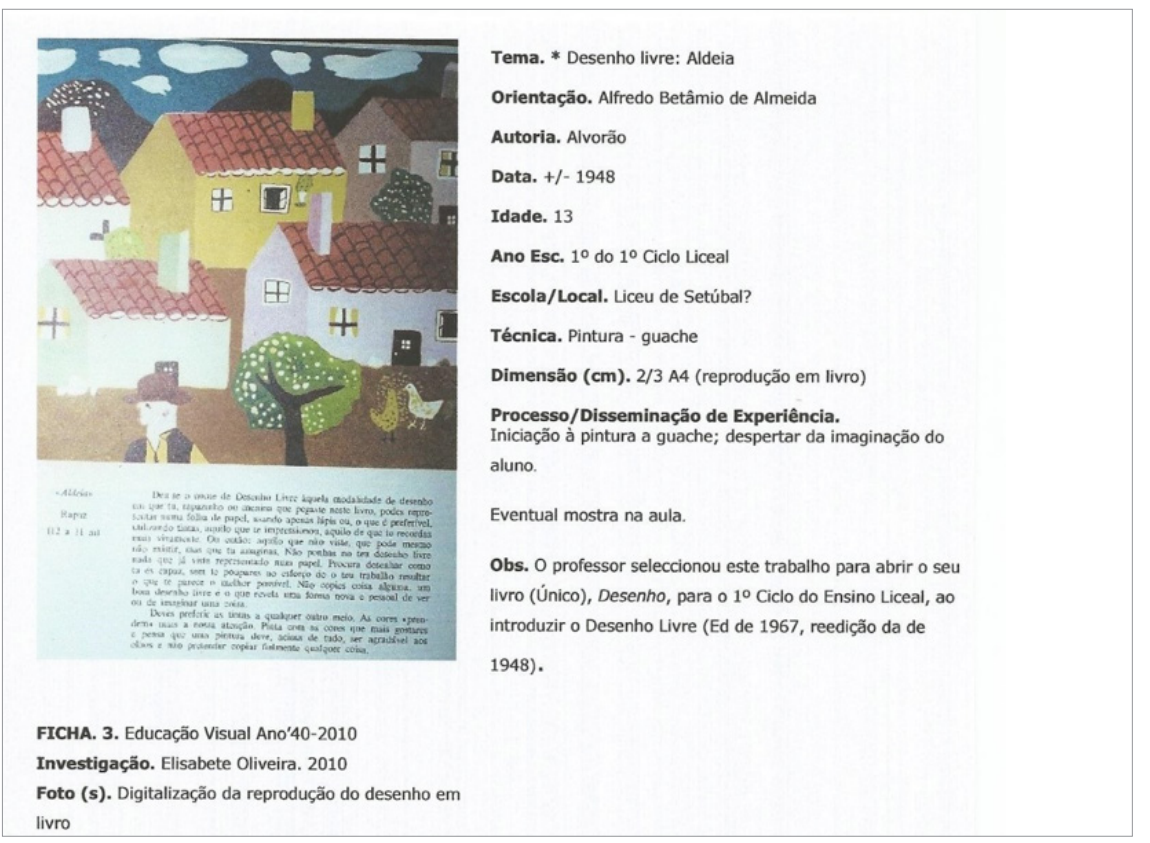

\subsection{Obra plástica de ABA}

Coloca-se a questão da prática artística do arte-educador em horário inteiro:

- Se o tempo livre reduzido só Ihe permite uma obra em menor quantidade e por vezes sincopada, tem de ser premeditadamente rotulada de arte menor?

Betâmio pintou fielmente por 20 anos (1965-1985) e procuraremos VER a sua obra sem preconceitos: atenderemos aos seus percursos de busca e evolver.

E procuraremos evidenciar o fluxo de profunda coerência entre a sua procura estética e, simultaneamente, a acção educativa de liberdade e trabalhos criativos propostos aos alunos.

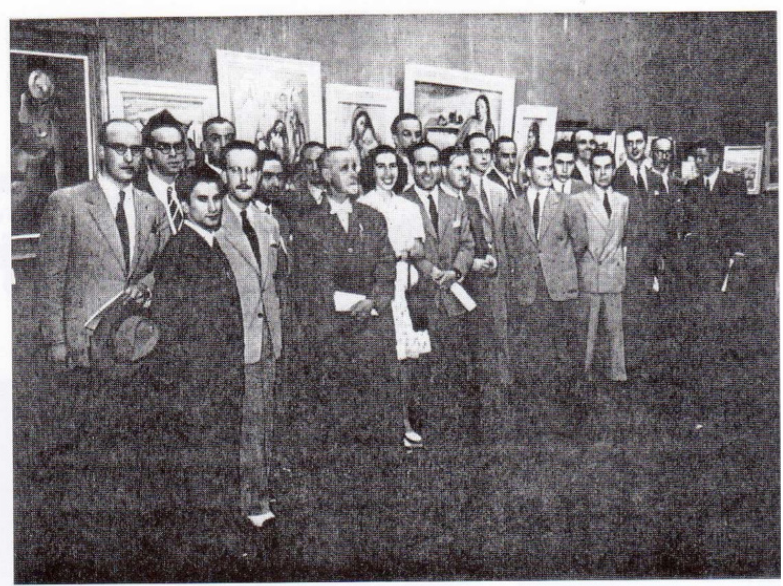

Fig. 5 - 1946

Foto de expositores da 1 a Exposição Geral de Artes Plásticas, na SNBA: Esquerda para a direita, fila da frente: Castro Rodrigues, Norberto de Ávila Falcão Trigoso, Maria Barreira, Vasco da Conceição, Keil do Amaral, Falcão Trigoso, Maria Barreira, Vasco da Concelção, Kell do Ama Fila de trás: Betâmio, Cândido Costa Pinto, ?, ?, ?, António Pedro, Fila de trás: Betâmio, Cândido Costân
Vespeira e Vasco Lucena, ?, ?, ?
Fig. 5. Desenho Livre de Aluno de Betâmio: Alvorão - 13 anos. 1948. In: Betâmio, A. (1948): Compêndio-Livro Único, reeditado por décadas. Ficha 3 - ExplorEAUL In: Oliveira. E. (2010).

Fig. 6. ABA entre os Artistas da 1a Exposição Geral de Artes Plásticas. SNBA 1946.

(Censurada pela PIDE): 1ํe em pé, à esquerda, 2aㅡ fila. In: Oliveira, E. (2010).

Percurso de ABA em Pintura: Do figurativo neorealista à abstracção 
Nos anos 40-50, ABA realiza desenhos de família. Dos guaches iniciais de $A B A$, destacamos:

- 1942 - paisagem-natureza morta naturalista, esfusiante de cor - árvore e abóboras, da casa materna benaventense (órfão de pai aos 4 anos);

1947 - (Cavador), próximo do sentir social neo-realista.

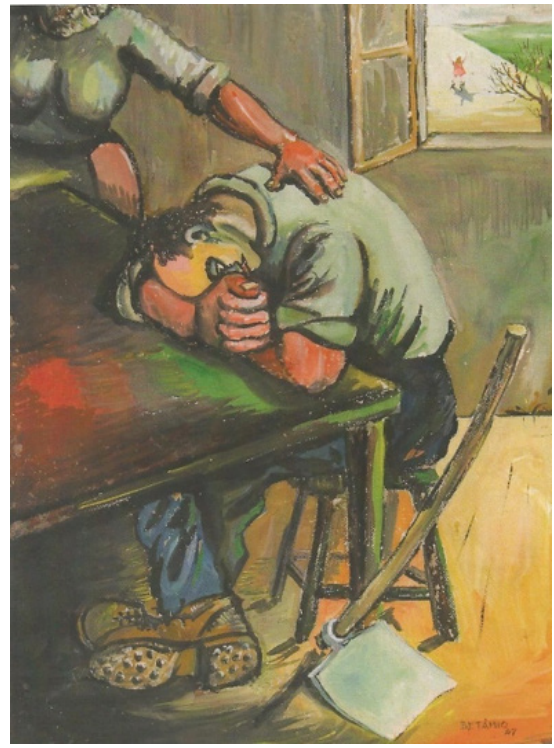

Fig. 7. Betâmio. (Cavador). 1947. Guache sobre papel, $50 \times 35 \mathrm{~cm}$. (Foto J. P. Queiroz)

Figs. 9 e 10. Betâmio. Pintura (pedras) c. 1966 \& 1967

Óleo sobre aglomerado: 60x80cm; $49 \times 72 \mathrm{~cm}$. (Fotos J. P. Queiroz)

Figs. 11 e 12. Betâmio. Pintura. 1968? \& 1968.

Óleo sobre cartão prensado, $71 \times 58 \mathrm{~cm}$ e $73 \times 54 \mathrm{~cm}$. Fotos de J P Queiroz

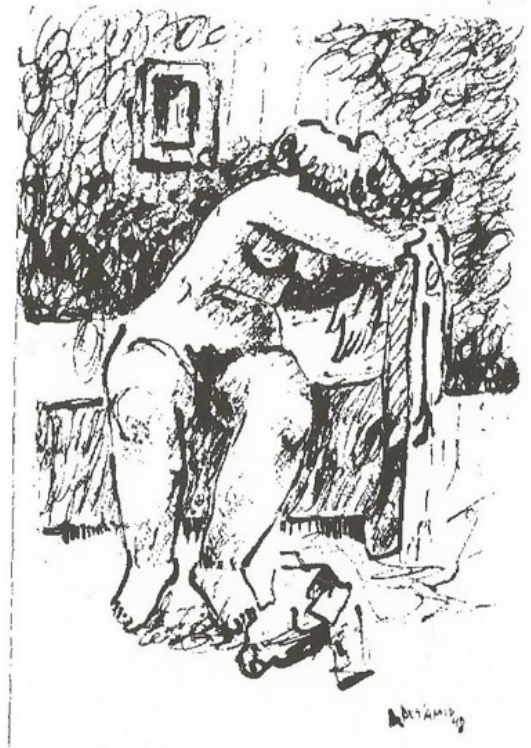

Fig. 8. Betâmio. (Nú). 1948. Desenho s/ papel. $18 \times 23 \mathrm{~cm}$. In: Oliveira, E. (2010).

Desde 1965, ABA - que se iniciara no óleo por 1959-60, pintando um muro e olival de Benavente -, explora o óleo, desenhando com a cor.

Debruça-se sobre pedras e tempo.
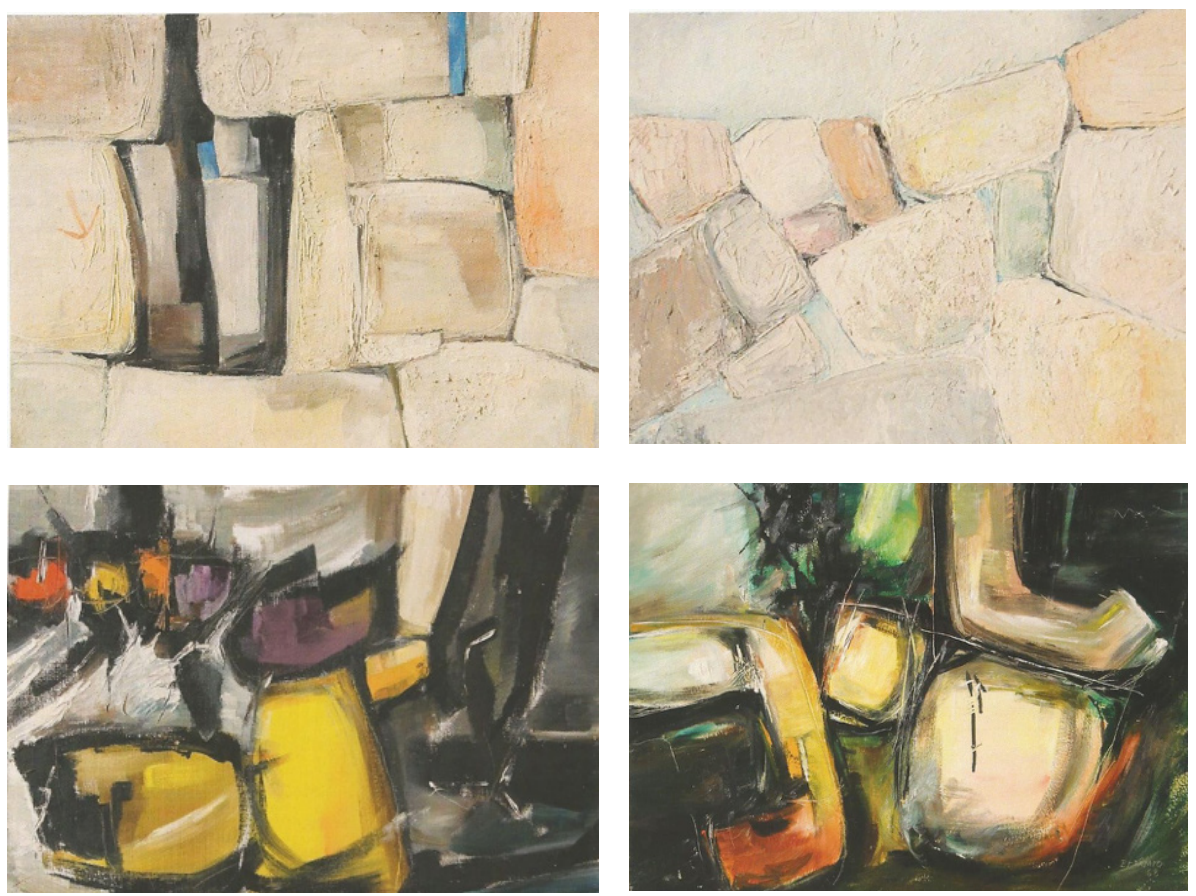
1968 terá sido o ano de maior produtividade de ABA em Pintura.

Mas algo doloroso e sufocado subjaz e transparece no quadro singular (Rosto), táctil, talvez reaproveitando o suporte. ABA não o mostrava, mas não o eliminou; e escreveu:

- A máscara é a nossa cara verdadeira vista do interior.

In: Betâmio (2007, 18 e 06.08.'83).

Cf. Damásio (2017, 365): A única origem da beleza é a ferida singular, diferente em cada um, oculta ou visível; e que Damásio associa à ideia de que o sentimento é um motivo-chave do processo cultural.

Betâmio reflectiu: Tenho sempre a angústia de não chegar a um 'momento' em que o quadro dependa mais de si próprio do que da minha vontade (...) creio mesmo que a aventura própria da arte moderna reside nisto. (Betâmio, 2004: 44; 2007: 18.04.'69).

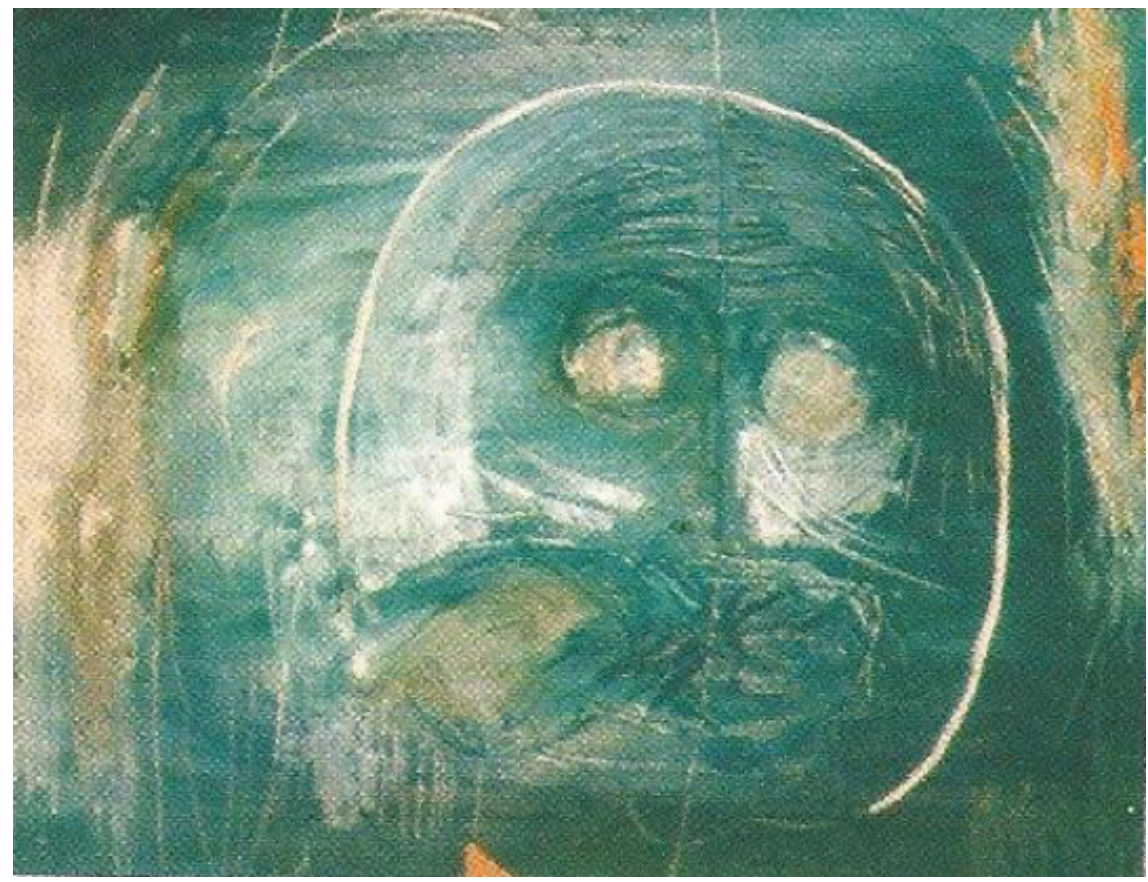

Em Betâmio haverá um sentido de oceanidade (Ehrenzweig, 1969 - obra que ABA reflectiu na altura do lançamento) que se articulará com o seu artigo sobre Amadeo como Pintor simultaneísta (Betâmio, 1969); e a concepção do Cubismo como concretização multisensorial.

Intensifica-se a busca de cor e movimento. A desmaterialização/ desconstrução cria atmosfera esvoaçante, explosiva, em obras designáveis de abstractas. (Visitas marcantes à Bienal de Veneza - Morandi - e Itália, ‘64; e ao Museu de Arte Abstracta de Cuenca '66).
Fig. 13. Betâmio. (Rosto). s/d: 2a metade de '60s Óleo sobre aglomerado, $60 \times 73 \mathrm{~cm}$. Foto Elisabete Oliveira 


\section{Vai-se diluindo a fronteira abstracto-concreto na pintura de $A B A$.}

Como notou Rui Mário Gonçalves, entre a alternativa de um quase impressionismo e a construção mais próxima do cubismo, optou por esta.

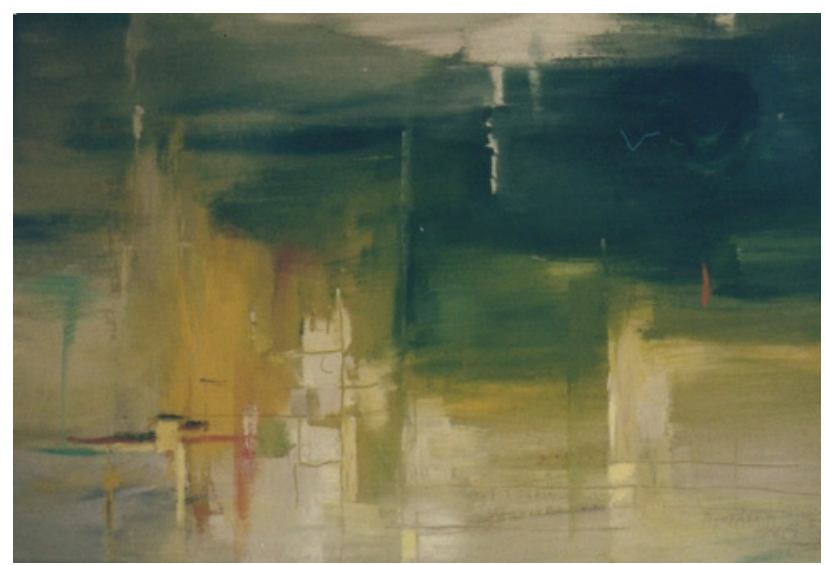

Fig. 14. Betâmio. Pintura. '67.

Óleo. Colecção e foto de António Ribeiro dos Santos (falecido, pelo que a obra passou a estar não localizável). In: Oliveira, E. (2018)

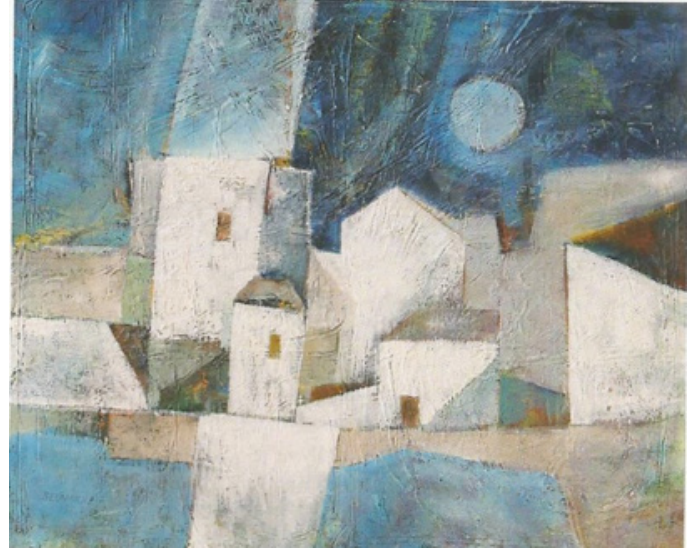

Fig. 15. Betâmio. Saudades do casario do Sul. '75.

Óleo sobre aglomerado. Foto: Queiroz, J. P. (2018).

A obra de arte é um resumo de mil horas de ver, ouvir e tocar. (...) A receptividade ao fluir da vida e ao rebate das forças vitais faz da arte um arado, ou coisa parecida, que garante o amanhã melhorado. Quando se diz que a arte é evasão, outra coisa não é de pensar que não seja a vontade de mais viver e de estar na vida com liberdade. (Betâmio, 2004: 36; 2007: 27.06.'76).

O valor da obra de Arte está na ressonância de um instante pessoal inencontrável duas vezes. A repetição é um fenómeno cultural mas não artístico. (Betâmio,2004: 38: 2007: 27.04.'69).

Em 1969, a via de arte abstracta esgotou-se, mas deixou rasto na pintura de ABA

\section{Dimensão Social - Função Comunicativa}

\subsection{Em Arte-Educação}

ABA dialogou, atento e em contínua actualização, a par da Arte e dos ArteEducadores pioneiros seus contemporâneos, como por exemplo, já em '55, recebendo Augusto Rodrigues que em '48 fundara a 1a Escolinha de Arte da América Latina, no Rio; encomendando livros do estrangeiro; expondo/ prefaciando Catálogos e intercambiando desenhos infanto-juvenis - por exemplo entre alunos do Liceu Pedro Nunes e do Liceu de Bruck a. d. Mur Áustria. 10.07.'62 - In: Palestra № 15, Julho 1962 -; visitando Exposições e Centros de Arte no estrangeiro como a Exposição dos 500 anos de Miguel Ângelo; Assis; e Bienal de Veneza em '64, ano da morte de Morandi; e, em '66, O Museu de Arte Abstracta de Cuenca e Benalmadena, pueblo do sul. Testemunhámos a sua liderança na 
metodologia do Desenho ('57-'58 até '72), nos Exames de Estado então tendo lugar nos Liceus Normais de Lisboa (Pedro Nunes), Porto (D. Manuel II) e Coimbra (D. João II), cujos Júris integrámos em '73; e indo em missão educacional por Portugal a Luanda em '70 e a Paris em '79, tendo visitado o Pompidou Centre.

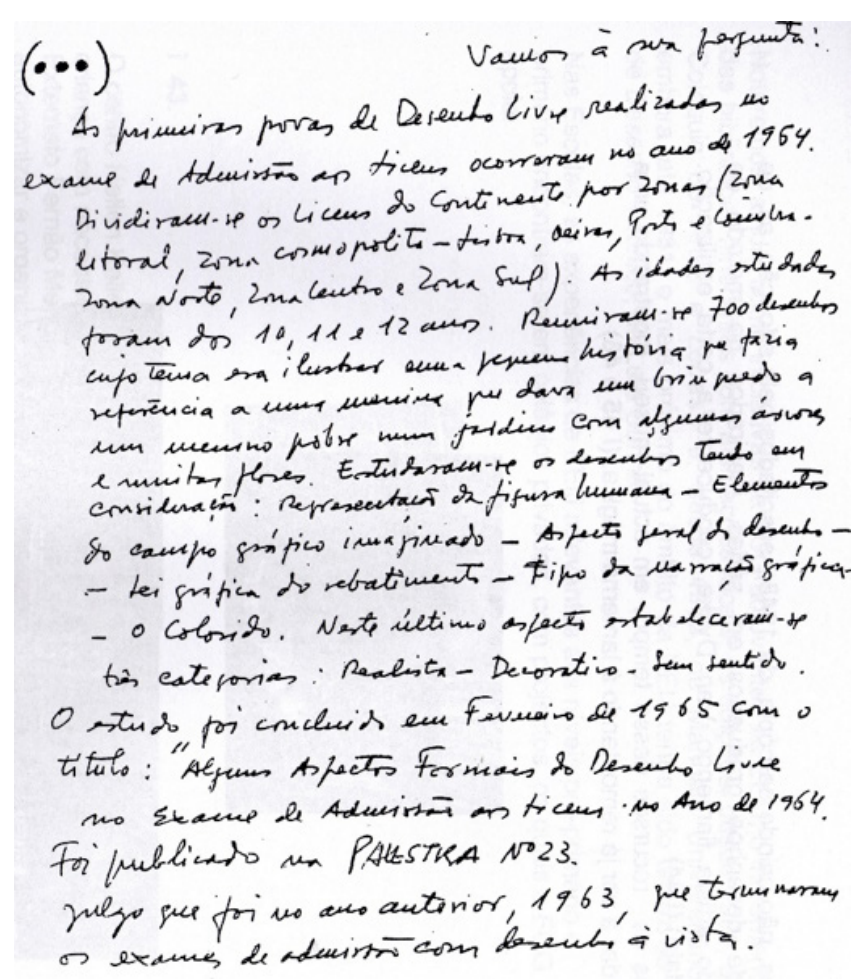

$(\cdots)$

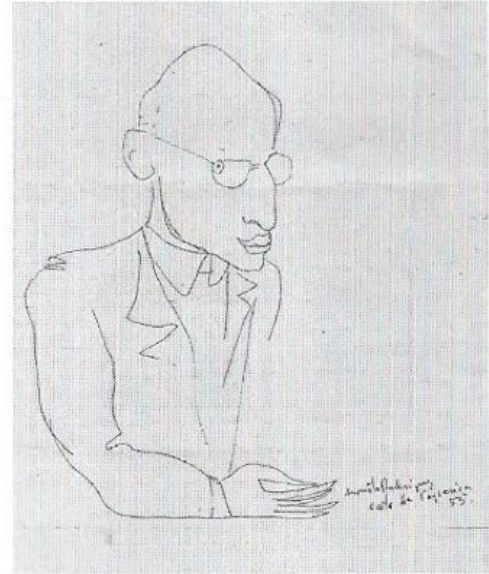

Fig. 16. Caricatura de Betâmio por Augusto Rodrigues, fundador da Escolinha de Arte, Rio de Janeiro1948, que o visitou na Costa da Caparica. 1953.
Fig. 17. Carta de ABA a E. Oliveira, 1984, sobre a sua Investigação de 700 desenhos livres, de admissão a Liceus do Norte ao Sul, 1964, após ter findado em 1963 o desenho à vista obrigatório.

\subsection{No desenvolvimento curricular em Desenho:}

À exploração livre, ABA alia o desenho analítico extensional dos objectos.

Desenho de observação por Alunos de Betâmio - Liceu Normal de Pedro Nunes.

In: Oliveira, E. (2010).
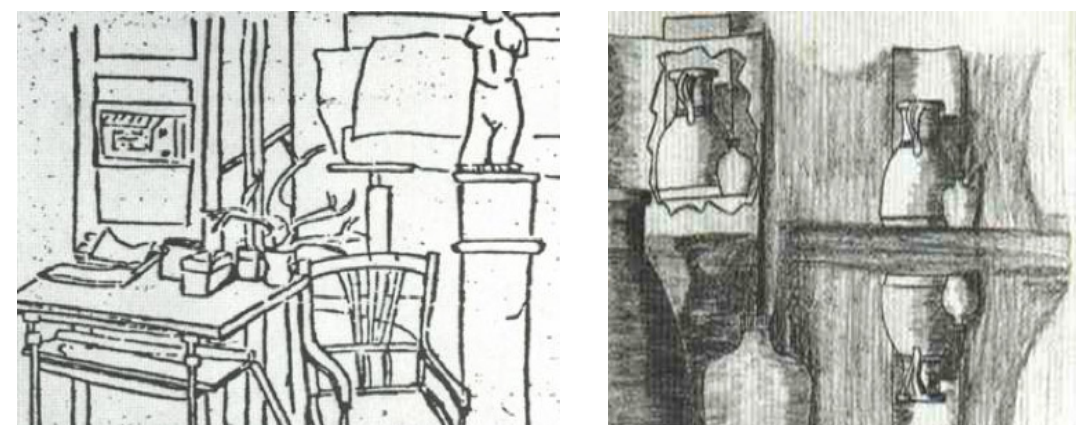

Fig. 19. Desenho analítico extensional, em aula, por Aluno

Fig. 18. Desenho da iniciativa do aluno, 14 de 15 anos (arquivo de ABA). 
Suceder-se-ão mais duas publicações referenciais:

- Educação Estética. Palestra № 31. Janeiro de 1968, seminal da mudança curricular bauhausiana de 1970 (com a sua Equipa atrás mencionada): o valor formativo da composição e da apreciação passa para os alunos.

- A Educação Estético-Visual no Ensino Escolar. Lisboa: Livros Horizonte. 1976.

ABA aprofunda o Estruturalismo e a Semiologia, com atenção a Charles Peirce. Com a sua Equipa - sendo especial o contributo de Danilo Sobral que fora estudar o Design da Alemanha -, coordena o novo Programa, bauhausiano, de Educação Estética Visual, '70.

É co-Director e Redactor de Palestra (Liceu N. Pedro Nunes), do 10 ao último número - Notas sobre a revolução estética do cubismo, in: № 42, 1973).

Co-responsável do lançamento do Ensino Unificado na Reforma de Veiga Simão (1975 - ), coordena a inovação curricular do âmbito da Educação Visual,10oe 7으 anos em '75; e, no 9o Ano, '77, a criação da Opção Vocacional de Arte/Design no 9o ano (esta, com colaboração de Danilo Sobral e Elisabete Oliveira). Em '76 escreve um dos Cadernos de Apoio a Professores (MEIC)-SEOP: Signos Visuais.

Fig. 20. Betâmio, A. \& AL. 1977: Página de Compêndio de Educação Visual 1, para o 7ํ Ano Unificado (não obrigatório), abrindo aos alunos a exploração semiótica e crítica da imagem.
Representação do Real. Coordena ainda Educação Visual 1 e 2 (7ㅇe e 8o anos), Didática Editora '77 - Compêndio para os novos Programas, não obrigatório -, com um grupo de seis Professores: Calos Sardinha, D. S. (Danilo Sobral), Elisabete Oliveira, Júlio Tuna, Moreira de Sousa, Pedro Fialho e Rocha de Sousa.

\section{O que é um signo visual}

É uma forma que, pelo menos, possui dois valores. Um, consiste naquilo que a forma em si própria, visualmente, apresenta. Outro, representa ou faz referên cia a algo.

Desde os começos da semiótica - ciência de criação recente que estuda os sistemas de sinais utilizados pelo homem que os signos visuais surgem divididos em: íconos, símbolos e índices.

Foi Charles S. Peirce quem, em 1867 fez esta distinção dos signos.

\section{Íconos}

Os iconos ou signos icónicos são as formas visuais que apresentam um esquema imitativo do objecto, um esquema mimético, mais ou menos carregado de co-realidade. Digamos, ainda, que a iconicidade é estabelecida por meio de códigos de reconhecimento e registada através de convençōes gráficas de raiz cultural. E é por haver, inevitavelmente, estas transposiçōes regradas que se fala em esquemas equivalentes de imitação. A figura humana, por exemplo, tem tido, através dos tempos, diversos esquemas de co-realidade. A arte não imita, anima-se, por vezes, de artifícios imitativos.
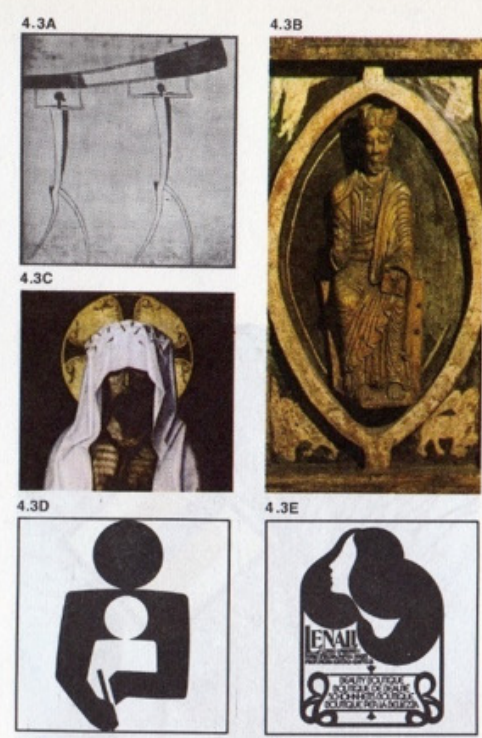

$4.3 \mathrm{~F}$

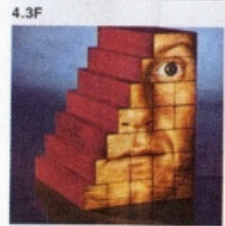

\section{Símbolos}

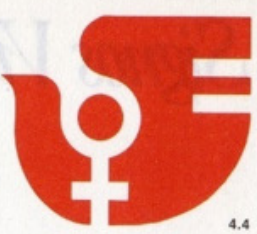

Os simbolos visuais são signos cujo significado é estabelecido por convenção. Símbolo, etimologicamente, significa reunião de dois sentidos: um visivel e outro oculto, um que é presente a qualquer pessoa, e outro só captado após iniciação.

\section{Índices}

São formas visuais que se tornam signos por acumulação da experiência fortuita. É um indice, por exemplo, para o caçador, 'o rasto de certo animal ou, para o comum dos mortais, o céu carregado de nuvens negras.

Conhece, por certo, o leitor, determinadas figuras visuais vulgarmente chamadas gráficos ou organigramas, como também já viu um quadro abstracto. Consideramos estas formas outros' signos fora da classificação de Peirce. Aos gráficos chamaremos signos lógicos, e para que possam ser lidos é ne- 


\subsection{Em Gestão Educacional e de Recursos Educacionais Visuais:}

Acumulando o cargo de Vice-Reitor do Liceu N. Pedro Nunes com a Metodologia desde '68, em 28.05.'74 deixou essas funções, em 22.08.'74 sendo nomeado Director Geral do Ensino Secundário e, em '17.01.'75, Inspector Geal do MEIC. Nomeado Presidente do ITE (Instituto de Tecnologia Educativa) em 22.03.'77 apesar de ter pedido Aposentação em '83 -, aí trabalhou até à morte em '85. No ITE, além da formação audio-visual de professores, ABA promoveu Colecções de diapositivos para as escolas, ele próprio tendo criado duas séries relevantes: A Escultura Medieval em Portugal/Séc. XV; e XVII Exposição Europeia de Arte. Ciência e Cultura, quando em '83 esta se realizou em Lisboa. (Arquivo actual na Universidade Aberta).

Betâmio preferiu a palavra compreensão a luta. (Betâmio, 2007: 15.10.'83). Poeta de vida e também de alguma escrita (Betâmio, 2007-Apêndice 1: '44-'60), integralmente, foi quem, no gigantesco desenvolvimento do Co. Propedêutico, incrementou um trabalho produtivo de 30h/semana de TV; 30000 estudantes/ ano; treino de 100 professores e 2000 monitores; 18 matérias ensinadas; 15 milhões de volumes com 65 títulos; aproximadamente 1 milhão de testes de exame e colaboração de 200 elementos de pessoal central e regional. (Fonte ITE; Betâmio, 2007). Abrindo caminho à Universidade Aberta: precedente referencial para o actual Estudo em casa, tele-recurso na emergência pandémica Covid 19, agora também online, geralmente por Zoom.

\subsection{Percurso de Betâmio em Pintura:}

\section{Da abstracção às naturezas-mortas}

Desde '69, ABA afirma o seu carácter mais marcante, explorando a reminiscência da cozinha velha e da mesa campesina, em diálogo aberto com os objectos:

- Com insistência, há um ano que pinto sem mudar o tema, e isto para lhe reduzir a importância. Procuro uma pintura que seja, antes de mais, uma atmosfera de cor não monocromática mas integrada como a montanha ou uma pedra. Pintura simples, primária, de formas cromáticas procuradas e solidárias. (Betâmio, 2004: 57; 2007: 07.03.76).

Preferências-Influências? A partir de 1976, ABA ensaia a Natureza-Morta, com especial atenção a Crivelli, Josefa d'Óbidos, Braque, Eduardo Viana e Morandi.

Excepcionalmente, surgem pinturas de casario branco, mediterrânico.

Sinto uma grande vontade de escrever sobre o que acontece de vulgar, mas que é transparente, revelador do que a vida tem de permanente (Betâmio, 2004: 70; 2007: 17.01.'85).

(...) Formas de paz, de uma grandeza chã como são as coisas próximas da terra. 
(...) Já comeu sopa de pão, perfumada de segurelha, com uma colher de pau? Procuro que a minha pintura tenha esse 'sabor' para os olhos.

(Betâmio, 2004: 61; 2007: 16.07.'80).

ABA procurava deliberadamente a irregularidade das formas e a marca riscada, raspada, da mão, coerente com o uso e o tempo que procurava nos objectos.

O tampo da mesa, de perspectiva invertida, contribuía para a desejada resultante bidimensional do quadro.

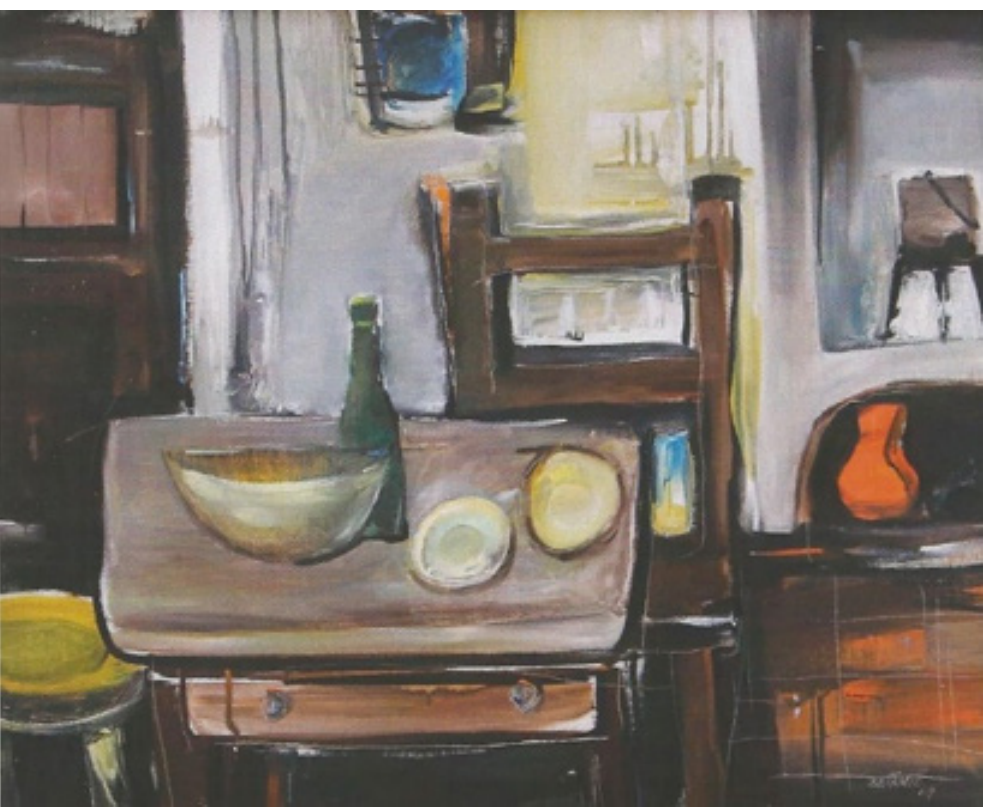

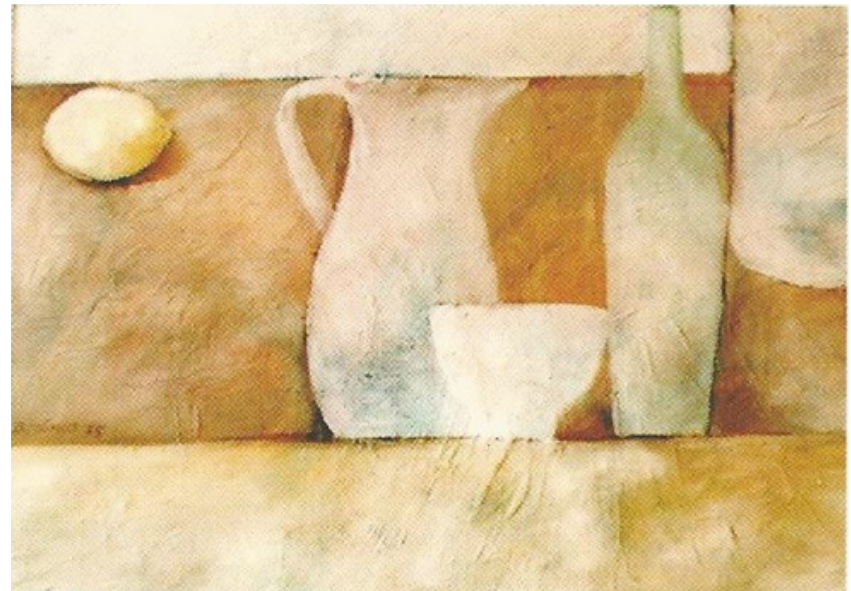

Fig. 22. Betâmio. (Natureza morta com limão). Óleo sobre aglomerado. 45×60cm). 1975 -período de profunda realização, com atelier agora na sua casa da Costa da Caparica. Foto: Oliveira, E. (2004).
Fig. 21. Betâmio. Cozinha velha. 1969. Óleo sobre tela. $65 \times 80 \mathrm{~cm}$. Foto J. P. Queiroz

\subsection{Obra literária}

Betâmio prosseguiu os ensaios, publicando em Palestra e pelo ITE; e desde '73, escreveu Textos Inevitáveis, continuando Textos sem nome que iniciara em '57.

\section{3. d. ontológica - f. organização-de-vida:}

Busca de sentido de Ser-Agir, do visível ao invisível, do possível ao imaginável. Reflexão partilhada, criando Arte, até ao fim. ABA Não se imaginava velho; morreria a dois dias da 3 a idade.

\subsection{Obra plástica}

Nos últimos óleos de Betâmio revela-se uma desmaterialização transparente: terra-a-terra mas transcendente?

Os quadros cercam-me, invectivam-me, são um empecilho, uma preocupação. Talvez acabe por destruí-los mas são a minha vida.

(Betâmio, 2004: 76; 2007: 06.08.'83) 


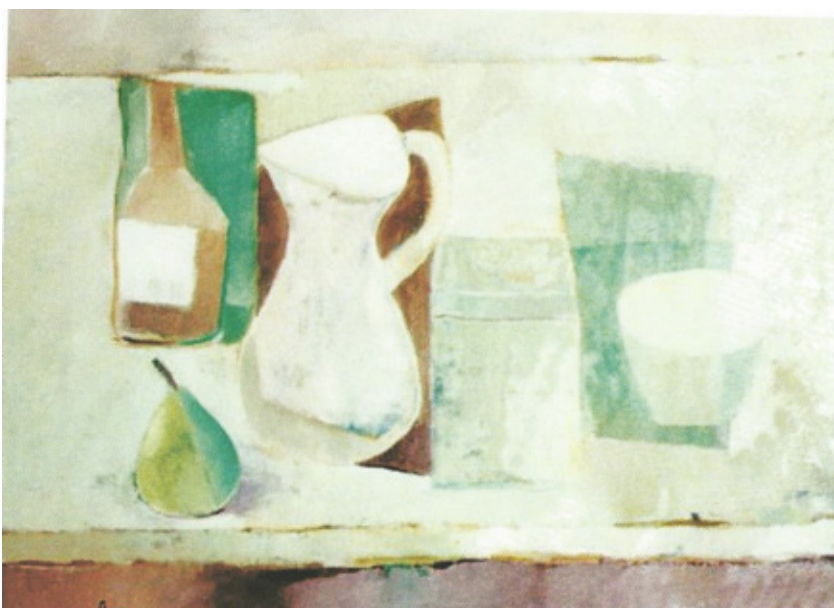

Fig. 23. (Natureza morta com uma pera). Óleo s/ cartão prensado 60x46 cm. 1982.

Foto: Oliveira, E. (2004)

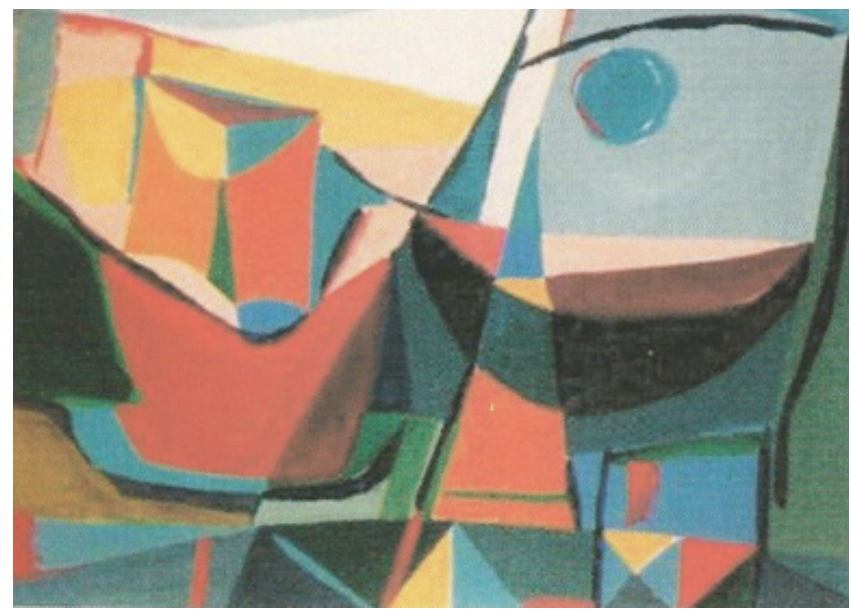

Fig. 24. Betâmio. (Paisagem com barcos) (1985). Guache s/ papel 22×16 cm. Última Obra do Autor.

(Foto: Elisabete Oliveira).

Nos dois últimos anos, com constrangimento do espaço-atelier, ABA volta ao guache e pinta até um mês antes de falecer, garrafas, frutos - as abóboras seus modelos iniciais... - e barcos, agora formas viva de cor: Formalmente, esta pintura terá maior afinidade com o 'cubismo' mas também se abre ao 'metafísico' (como em Morandi) pela transcendência existencial e simbolismo reconhecidos no objecto comum usado. (...) 'Ver' é um acto criador. (Betâmio, 2007: 05.10.'83). O cerebral cederá à vivência do saboreado/desejado; e romper-se-á a fronteira concreto-abstracto, quando conseguida a desejada atmosfera de cor, fresta para um jogo de contrastes quase sem fim.

Resta ficar na praia vendo os barcos da aventura voltar. (Betâmio, 2004: '75; Betâmio. 2007: Ago '77).

\subsection{Textos Inevitáveis e obras póstumas}

É de '80, a sua Comunicação Art Education e o Espírito Europeu, à NSAE-National Society for Education through Art, UK. De Janeiro '85 dataram o último ensaio, $\mathrm{O}$ conceito de desenho e de pintura em Diderot, a Congresso na FCG no qual já não pôde participar; e o último dos Textos inevitáveis - Betâmio, A. (2007) - 17.01.85:

- Sinto uma grande vontade de escrever sobre o que acontece de vulgar, mas que é transparente, revelador do que a vida tem de permanente. 0 eléctrico deixoume no Largo do Camões e olhei um prédio com lindos azulejos.

Recordei o Conceição Silva e a verdade da sua morte. Era ali um dos seus ateliers. Depois comecei a sentir-me cansado de tudo. Foi uma tarde dramática. Não encontro a palavra certa para traduzis a estranha mistura do sentimento de morte com a ânsia de querer a Primavera que me tomava a respiração. 


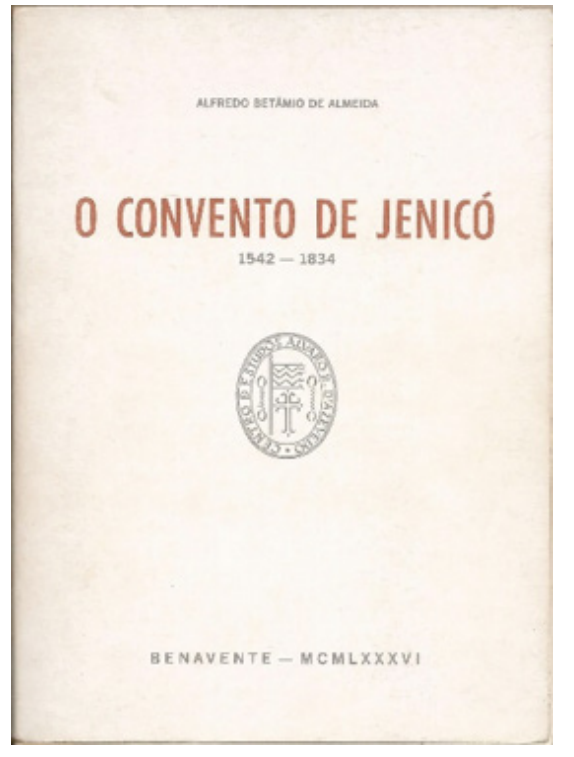

Fig. 25, 26 e 27. As três obras póstumas de ABA.

. Betâmio, A. (1990). O Convento de Jenicó. Benavente: Câmara Municipal. Montagem Editorial: Oliveira, E. (DL: 36106/90). 2a Edo, 2000, celebrando os 800 anos do Foral de Benavente. 127pp \& Colecção anexa de 6 postais de desenhos do Livro e aguarela etnográfica ribatejana por ABA.

. Betâmio, A. (2004). Pintura. Benavente: Câmara Municipal/Museu Municipal. Coord.: Oliveira, E. Prefácio: Gonçalves, R. M. (ISBN: 972-99201-0-9). 132pp

. Betâmio, A. (2007). Textos Inevitáveis. Benavente: Câmara Municipal; Educa - FPCE. UL; e Apoio da Reitoria da Universidade de Lisboa. Coord.: Oliveira, E. Prefácio: Carvalho, R. (ISBN: 978-972-8036-95-9; ISBN: 978-972-99201-2-7). 443pp.

\section{P I N T U R A}

Alfredo Betâmio de Almeida

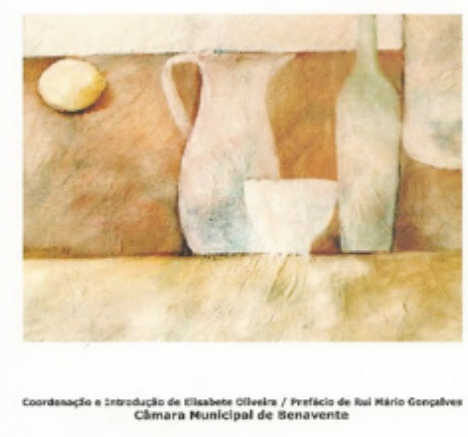

TEXTOS INEVITÁVEIS

Alfredo Betâmio de Almeida

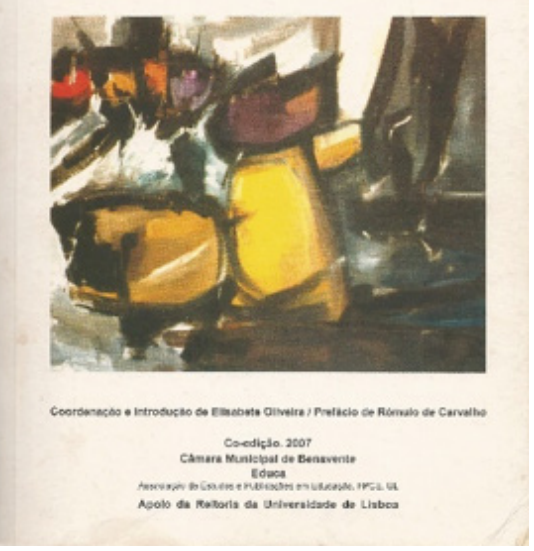

Posteriormente, sobre ABA, destacamos duas publicações:

. Queiroz, J. P. \& Oliveira, E. Betâmio de Almeida (1920-1985): A Pintura de um Educador pela Arte. Lisboa: Colecção Educação Artística № 1. CIEBA-FBAUL. Março 2018.

. Oliveira, E. A Pintura de Betâmio: Essencialidade do objecto comum e atmosfera da cor nos 70 anos do “Desenho Livre” nos Liceus portugueses. In: GAMA № 11. Lisboa: CIEBA-FBAUL. 2018.

Em Betâmio, A. (2007), 23.06.'84, é referido que, como Agostinho da Silva, viu a sua nomeação para condecoração no 10 de Junho ser preterida (acrescentamos: para a Directora de Ensino Secundário Alice Gouveia). Postumamente foram-Ihe atribuídas, pela C. M. Benavente: Medalha de Mérito Municipal (1991); Medalha das comemorações do VIII Centenário do Foral (2000); e Nome de uma rua de escola em Benavente (2007).

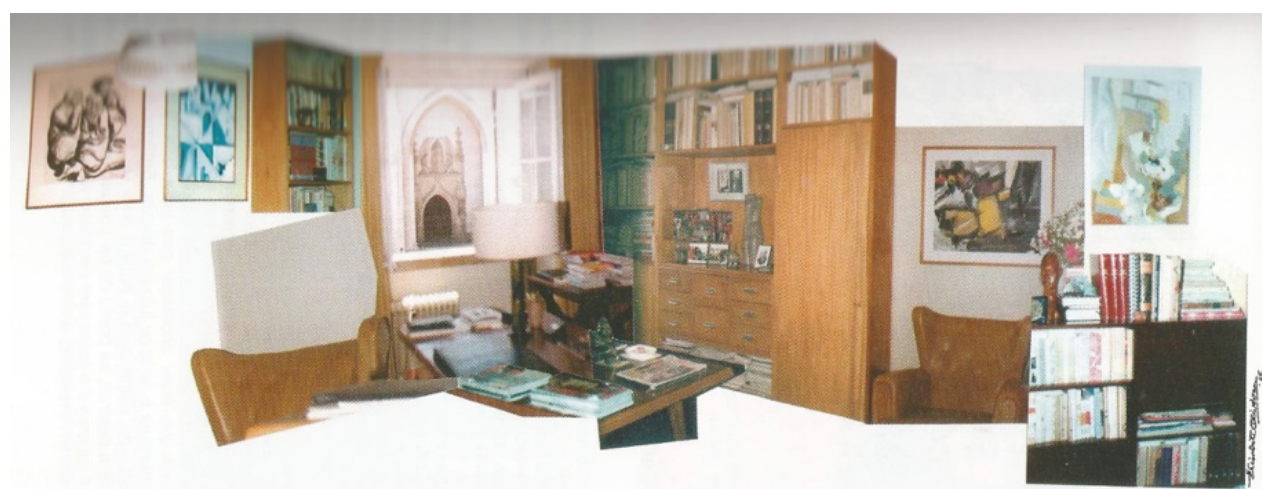

Fig. 28. Escritório de $A B A$ na sua casa de Campo de Ourique, frente à igreja do Santo Condestável - que aqui entra pela janela -, após o seu falecimento. Exactamente no ângulo inferior direito, no móvel escuro, junto ao chão, estão - tal como os deixou -, os Cadernos manuscritos de ABA com os Textos Inevitáveis. (Fotomontagem de E. Oliveira, 1985). Vêem-se quadros de Resende, Manuel Filipe, ABA e Elisabete Oliveira; uma escultura de Ma Luisa Abelha e uma gravura do filho, António Betâmio de Almeida. In: Oliveira, E. (2007). 


\section{Única Exposição de Naturezas-mortas em vida de ABA. Exposições póstumas}

Desde as Exposições Gerais da SNBA, '46 e ‘47, a 1a exposição, c. 1981-82 - segundo

Moreira da Silva, Vice-Presidente de ABA no ITE -, terá sido numa sala da Galeria

111, Co Grande, do amigo Manuel Brito que ele iniciara nas Artes, ajudando-o à composição das montras da anterior Livraria (e Tertúlia discreta), da Escolar Editora (R. Escola Politécnica).

\section{A 1ạ e única Exposição individual de NATUREZAS} MORTAS, em vida, foi no Museu da sua Benavente, 1982.

A 1a Exposição Póstuma foi Inaugural da Galeria Municipal de Arte de Benavente, 2004. Curadoria de Cristina Gonçalves e Elisabete Oliveira.

Não procuro uma representação extremamente rigorosa, quedo-me por um desenho que não vai muito além da sugestão. Procuro simultaneamente, introduzir um sentido de liberdade. Pintura situada entre o realismo e a abstracção lírica. (Betâmio, 2004). Não busco qualquer pintura de vanguarda. Quero apenas algo de amável e recolhido. Pintura, portanto, fora do tempo. (Betâmio, 2004).
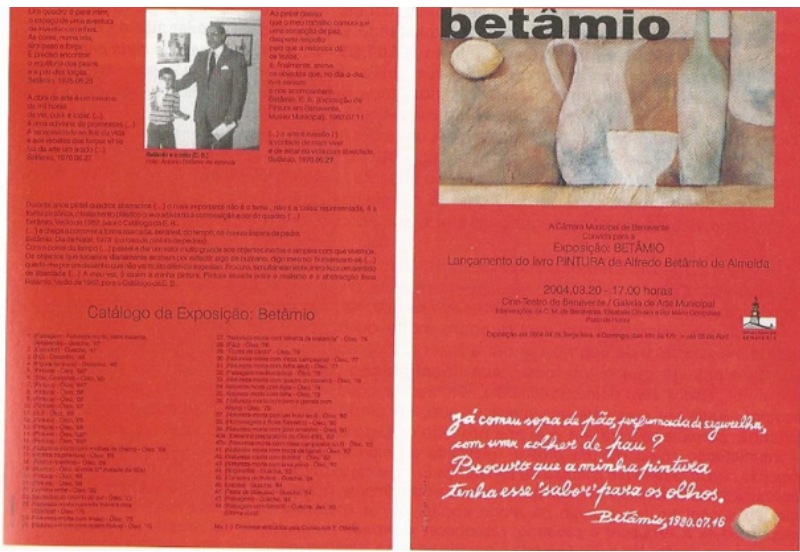

Fig. 29. Betâmio - 1ạ Exposição Póstuma de Pintura. 2004.

Flyer-Catálogo-Convite (Grafismo e foto: Elisabete Oliveira).

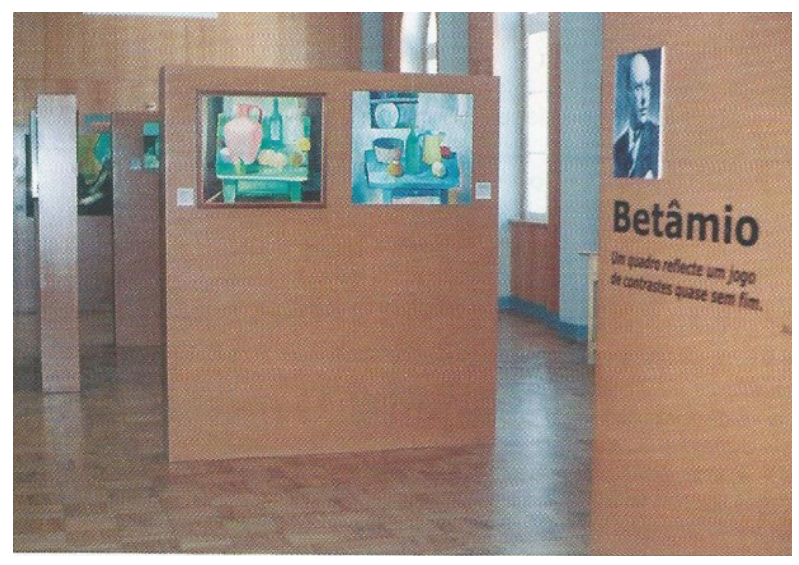

Fig. 30 - 1ạ Exposição Póstuma de Pintura de Betâmio. 2004. Entrada da Galeria da Exposição. foto: Elisabete Oliveira).

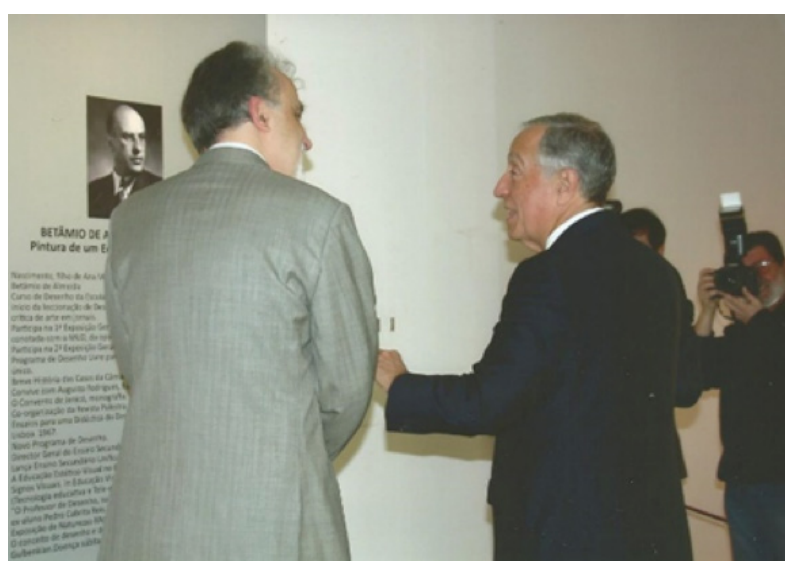

Fig. 31 - 2a Exposição Póstuma de Pintura de Betâmio. 2018.

Curadoria de João Paulo Queiroz, António Betâmio de Almeida e Elisabete Oliveira SNBA: Inauguração pelo PR, Professor Marcelo Rebelo de Sousa. (Foto: Elisabete Oliveira).

A raiz da vida hologramática de $A B A$ e da sua atenção ao objecto comum, poderá encontrar-se num despojamento 'franciscano':

Homem habituado a caminhar só, vagabundo de não sei quê, apaixonado de um pequeno largo de uma terra à beira do Mediterrâneo, pronto a ser feliz com quase nada desde que coisa simples, como pão e azeitonas, ou vinho e mel. E 
é com esta alma de franciscano que fico fora do tempo, não sei se perdido, se encontrado. (Betâmio, 2004: 72; 2007: 1972).

Rui Mário Gonçalves (Gonçalves, 2002), acentua a visão, o tacto e a memória na obra de ABA; regista que, nos anos ' 60 , a pintura de ABA 'oscilava entre as tendências informalistas (gestual e matéria) e outras mais construídas'; e analisa:

(...) As pinturas de Betâmio são produto de quem é professor, empenhado em aprender por conta própria, as lições dos mestres (...) O pintor impôs as suas regras, as mais simples, para montar e desmontar à vontade os mecanismos do acto da visão e do seu registo, num processo que se abre ao poder evocativo

Repare-se na imaginação de Betâmio de Almeida. Ela manifesta sempre o sentido do essencial.

Tivemos o privilégio de partilhar a sala de aula de $A B A$ (paredes com rotação de reproduções de Arte motivantes) e Gabinete de Desenho anexo, no topo direito do Liceu Normal de Pedro Numes, em 1965-67 tendo-o como Metodólogo e, de 1967 a 1969, como Colega: às 2as f, a s, mostrava-nos a pintura que fizera a cada sábado.

Um episódio que testemunha a determinação e pertinência de acção de ABA:

Na 2a metade dos anos '60, o Presidente da República Américo Tomás viria ao Liceu para entregar um livro de prémio ao melhor aluno, Marcelo Rebelo de Sousa. A Sala de Professores, com um palco morto há muito, cheirava a bafio. Numa semana, só com a ajuda de funcionários, ABA tudo desmontou e recriou, até aos modernos candeeiros de metal e vidro no tecto: No dia da festa, resplandecia... só se temia que a tinta das paredes não tivesse tido tempo de secar!
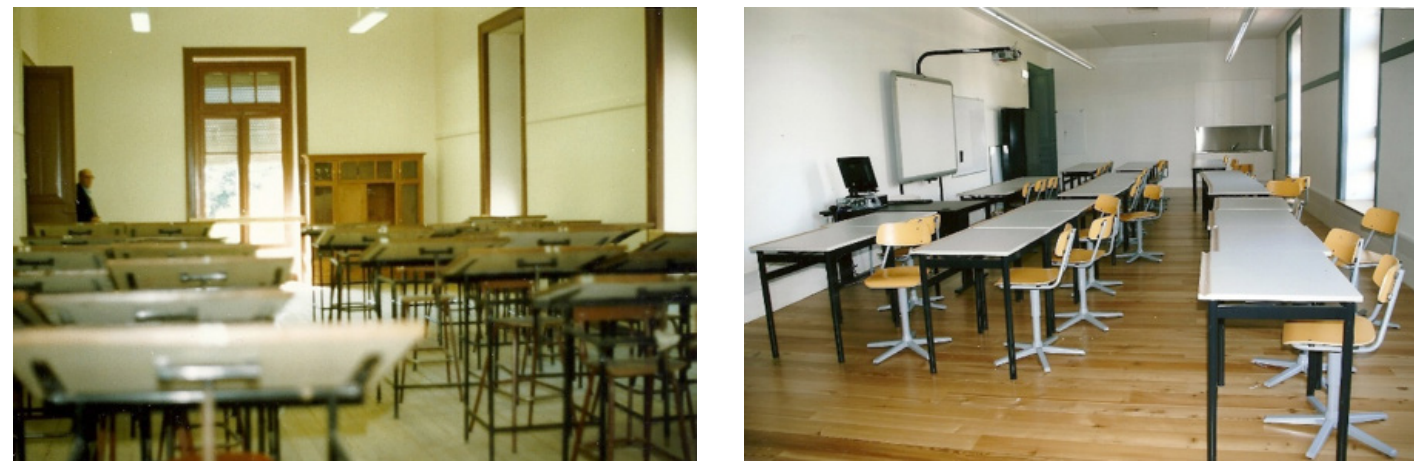

Figs. 32 e 33. Sala de aula 33-Desenho de Betâmio, no Liceu Normal de Pedro Nunes; e actual, na Escola Secundária de Pedro Nunes, após intervenção da Parque Escolar. (Fotos de E. Oliveira, respectivamernte em 1989 e 2010). (Oliveira, E. 2010)

\section{REFLEXÃO conclusiva}

\section{QUAL A VALIDADE REFERENCIAL DA OBRA DE ABA PARA A ARTE-EDUCAÇÃO DO PRESENTE-FUTURO?}

ABA propôs caminhos de crescente autonomização de crítica/expressão/ comunicação pelos alunos.

Notamos, nas Fig.s 32 e 33, uma orientação diversa do eixo da sala/iluminação e a acentuação do equipamento de visualização, que nos colocam o questionamento 
do equilíbrio das experiências de apreciação vs. concretização de projectos dos alunos; consideramos que o valor formativo destes projectos deve continuar a ser fundamental: actualmente, estará mais facilitada a dinâmica de projecto em equipa; um ponto de água no fundo da sala, apontará à salvaguarda da manualidade; e com as tecnologias emergentes, será precisa uma vigilante autoeco-compatibilização contínua. Considerando a conquista em Educação Estética Visual que tem sido o Projecto de trabalho assumido em grupo e partilhado com a comunidade nacional/internacional, consideramos que este processo terá de ser salvaguardado, em auto-eco-compatibilização com o instrumental tecnológico emergente.

Para que a obra de ABA possa ser explorada como referencial por Professores, Alunos e na Cultura, está em progresso, projectado para '20-'21, o plano de Celebração do Centenário de nascimento - ABA100, incluindo a presente Evocação pela APECV e na Revista Invisibilidades. Compreende ainda:

Publicação das Obras Completas de ABA (faltando a Investigação de Imprensa...) / Congresso com Call for papers e Actas online /Exposição de ABA e Pioneiros Afirmados e Emergentes em Artes Visuais- Educação (Publicações, Obra Plástica e Projectos escolares orientados) + Catálogo / Patronagem-Escola Secundária de Benavente / Espólio de Livros pa a FBAUL...

Sobrevoando o legado de vida-obra de $\mathrm{ABA}$, em síntese consideraremos:

\section{Em Arte:}

A pintura de abstracção lírica ( $A B A)$, terá sido um campo experimental da sua visão, ensaio de técnicas e explorações correspondentes às energias e tensões emergentes relevantes para ele; terá sido operacional e servido de contraponto para as naturezas mortas, onde atingirá a sua mais distinta expressão: esta caracterizar-se-á pela busca da essencialidade a partir do instante e do comum, num realismo ( $A B A)$ em tensão vivencial radical - sensuo-poético; num préecologismo respeitando o dado chão, usado... grandeza chã como são as coisas próximas da terra (ABA).

Na criação literária, deixou-nos os seus notáveis textos inevitáveis - estéticos, reflexivos, críticos e poéticos.

A arte $A B A$ está investida de hologramaticidade precursora de uma visão contemporânea.

\section{Em Educação:}

(1) Planeamento e operacionalização curricular em Educação Estética Visual impulsionando a formação e exposições de trabalhos visuais de crianças mas, sobretudo, a expressão dos Adolescentes. 
(2)Planeamento e operacionalização curricular para o Ensino à distância, Telescola e Curso Propedêutico precursor da Universidade Aberta.

(3) Formação de Professores, quer na Metodologia presencial, quer na do ensinoaprendizagem à distância (inevitável ao tempo, em contextos de constrangimentos geográfico, económico-sócio-cultural...; mas sempre apoiando uma Relação Professor-Alunos tendo em contra as Pessoas em presença. E publicando livros de suporte didáctico essencial.

4) Criação de Estruturas, Dinâmicas e Recursos, numa responsabilização cívica que sustentou o esforço de $A B A$ para resolver burocracias, miopias institucionais e outras causas de desperdício de tempo vital e de operacionalidade. Rómulo de Carvalho, no Prefácio de Betâmio (2007), acentuou (em ABA) o sofrimento de um ser humano que se sentiu (...) limitado (...) por si mesmo - um capital que não se deve desprezar.

Julgamos mais justa a palavra insatisfação, no sentido de uma ambivalência e insatisfação contemporâneas como dúvida global, que Bhabha (2007) considera que permite a compreensão de que podemos aspirar à transformação, acreditando no futuro sem esquecer o passado e criando um mapa para a acção... E Betâmio foi, até ao fim, uma Pessoa de contemplação, mas sobretudo, de acção.

\section{Referências Bibliográficas}

Bhabha, H. (2007). A Urgência da Teoria. Lisboa: FCH, Pp 42-3.

Betâmio, A. (1948). Compêndio de Desenho para o 1ํ Ciclo dos Liceus. Lisboa: Sá da Costa. Edições sequentes como Livro Único; actualização em 1967.

Betâmio, A. (1967). Ensaios para uma Didáctica do Desenho. Lisboa: Escolar Editora. (1968). Uma Visão Táctil: Eduardo Viana. In: Diário de Lisboa, anos '60-'70.

Betâmio, A. Betâmio, A. (1968a). A Educação Estética. In: Palestra № 31. Jan.

Betâmio, A. \& AA. (1968b). Curso Básico de Arte - Um Novo Desenho dos Liceus. In: Palestra № 31.Jan. (AA-Equipa de ABA: Abelha, M L; Dantas, S; Viola, M E; Oliveira, E; Sobral, P; Dantas, F; e o Colega do L N Pedro Nunes, Ferreira, L.) - Base do Programa de Educo Visual nacional de '70. Betâmio, A. (1969). Amadeo de Souza-Cardoso, Pintor Simultaneísta? In: Palestra. № 35/36. Jul. Betâmio, A. (1976). A Educação Estético-Visual no Ensino Escolar. Lisboa: Livros Horizonte. Betâmio, A. \& AA. (1977). Educação Visual. Vols. 1 e 2 (7ํ e 8o Anos de Escolaridade). Lisboa: Didáctica Editora. Compêndio para alunos; não obrigatório. Betâmio, A. (1982). Catálogo da Exposição de 'Naturezas-Mortas'. Museu de Benavente. Betâmio, A. (1990). O Convento de Jenicó. Benavente: Câmara Municipal. Montagem Editorial: Oliveira, E. (DL: 36106/90). 2aㅡ Edo, 2000, 800 anos do Foral de Benavente. Betâmio, A. (2004). Pintura. Benavente: Câmara Municipal/Museu Municipal Coord.: Oliveira, E. Prefácio: Gonçalves, R. M. (ISBN: 972-99201-0-9). 
Betâmio, A. (2007). Textos Inevitáveis. Benavente: Câmara Municipal; Educa; e Apoio da Reitoria da Universidade de Lisboa. Coord.: Oliveira, E. Prefácio: Carvalho, R. (ISBN: 978-972-8036-95-9; ISBN: 978-972-99201-2-7).

Carvalho, R. Alfredo Betâmio de Almeida, um homem singular. In: Betâmio (2007), Prefácio.

Damásio, A. (2000). O sentimento de si. O corpo, a emoção e a neurobiologia da consciência. MemMartins: Publicações Europa-América. 2001.

Damásio, A. (2017). A estranha ordem das coisas. A vida, os sentimentos e as culturas humanas. Lisboa: Temas e Debates. Círculo de Leitores, 365.

Eco, U. (1964). L' oeuvre ouverte. Paris: Ed. Du Seuil.

Ehrenzweig, A. (1969). A ordem oculta da Arte. Um estudo sobre psicologia da Imaginação Artística. R Janeiro: Zahar Editores.

Genet, J. (S/ d). L’ Atelier de Alberto Giacometti. In: Damásio (2017, 365).

Gonçalves, R. M. (2002). A visão, o tacto e a memória. (Betâmio, 2004: 10-12)

Morin, E. (1990). Introdução ao pensamento complexo. Lisboa: Io. Piaget. 1991

Oliveira, E. (2010). Educação estética visual eco-necessária na Adolescência. Coimbra:

MinervaCoimbra.ISBN:978-972-798-293-6. Oliveira, E. A Pintura de Betâmio: Essencialidade do objecto comum e atmosfera da cor nos 70 anos do "Desenho Livre" nos Liceus portugueses. In: GAMA № 11. Lisboa: CIEBA-FBAUL. 2018.

Peirce, C. (1958). Collected Papers. Vol. 8. Harvard: Harvard University Press.

Queiroz, J. P. \& Oliveira, E. Betâmio de Almeida (1920-1985): A Pintura de um Educador pela Arte. Lisboa: Colecção Educação Artística № 1. CIEBA-FBAUL. Março 2018.

\section{Sobre a Autora Elisabete (S.) Oliveira.}

N 1942 em Lisboa, onde reside. Pintora pela ESBAL,1965, expondo desde 1952 (Infantil) e 1964; última participação: Foto, APECV32 online, Maio 2020. Diplomada em Art/Design Education pelo IE-University of London. Professora Auxiliar FPCE/IE.UL-Ph D-C.s Ed - UL, 2005.05, Aposentada em 2006 com 40.5 anos de Docência-Investigação-Acção nos Ensinos Secundário e Universitário,

Actual Investigadora pro-bono, CIEBA-FBAUL com o Projecto ExplorEAULExploratório de Ed. Artística da Universidade de Lisboa (Poneiros Afirrmados e Emergentes-Projectos). Planeadora/Consultora Curricular nacional 19702001, introdutora de Arte/Design (9ํํㅜ, nacional) e Integração das Expressões. (Educ. Pré-Escolar. Univ. Açores). Formadora de Professores/ Investigadores (E. Magistério Primário, Coimbra; UL; Univ. Açores; IPL-ES Teatro e Cinema). 1a portuguesa Conselheira Mundial InSEA/UNESCO (1988-1997), conferenciando e publicando em cinco continentes. Autora de mais de 100 artigos, uma dezena de livros/partes de livros e CDs, com Tese actualizada em Educação Estética Visual Eco-Necessária na Adolescência. 2010. Co-fundadora de: SPZC/SPRC, APECV, SPCE-Educação e Arte, MPIAEPA/MOVEA, colaborando com Autarquias/Museus/ Bibliotecas/Fundações e Centros de Recursos Audiovisuais. 